\title{
Carrot somatic embryogenesis depends on the phytohormone-controlled presence of correctly glycosylated extracellular proteins
}

\author{
Sacco C. de Vries, ${ }^{1}$ Hilbert Booij,, ${ }^{1}$ Rob Janssens, ${ }^{1}$ Ronald Vogels, ${ }^{1}$ Laura Saris, ${ }^{1}$ Fiorella LoSchiavo, ${ }^{2}$ \\ Mario Terzi, ${ }^{2}$ and $A b$ van Kammen ${ }^{1}$ \\ ${ }^{1}$ Department of Molecular Biology, Agricultural University Wageningen, 6703 BC Wageningen, The Netherlands; \\ ${ }^{2}$ Department of Molecular Biology, University of Naples, 80134 Naples, Italy
}

Proteins excreted into the culture medium by carrot cells during somatic embryogenesis in the absence of 2,4dichlorophenoxy acetic acid (2,4-D) and during unorganized cell proliferation in the presence of 2,4-D were analyzed by SDS polyacrylamide gel electrophoresis (PAGE). During somatic embryogenesis extracellular proteins with apparent molecular masses of $13,17,29,38$, and $46 \mathrm{kD}$ were released into the medium. These proteins were reduced or absent in media of 2,4-D-grown cells. In contrast, cells grown in the presence of 2,4-D released proteins with apparent molecular masses of $27,36,40,44,48$, and $72 \mathrm{kD}$. Concanavalin A staining revealed that the 29-, 46-, and $72-\mathrm{kD}$ proteins as well as a doublet of $52 / 54-\mathrm{kD}$ extracellular proteins were high-mannose type glycoproteins. Carrot cell lines impaired in somatic embryogenesis failed to release one or several of these proteins or produced aberrant forms in the absence of 2,4-D. Somatic embryogenesis in cell lines missing one or several extracellular proteins were partially restored after addition of extracellular proteins obtained from embryogenic cell lines. In contrast, cell lines producing aberrant forms of extracellular proteins could not be complemented. Somatic embryogenesis could be completely blocked by tunicamycin and deoxynojirimycin. Tunicamycin treatment resulted in the presence of deglycosylated forms of the 46- and 52/54-kD extracellular proteins; deoxynojirimycin treatment resulted in higher molecular mass forms of the 52/54-kD glycoproteins. Somatic embryogenesis in tunicamycin-blocked cultures but not in deoxynojirimycinblocked cultures could be completely rescued by addition of extracellular proteins from untreated embryo cultures. The complementing extracellular proteins were active in a narrow concentration range of 1-3 nM if a single protein was involved. The complementing activity was only found in media from embryogenic cell lines. Microscopical observation of tunicamycin-treated cells revealed that embryogenesis was affected at a very early stage, before globular stage embyros are formed. These results demonstrate that the phytohormone-controlled release of several extracellular proteins that must be correctly glycosylated for their activity is essential for carrot somatic embryogenesis to occur.

[Key Words: Daucus carota; somatic embryogenesis; plant glycoproteins; plant extracellular proteins; tunicamycin; deoxynojirimycin; plant cell differentiation; auxin; cytokinin; developmental mutants]

Received November 16, 1987; revised version accepted February 5, 1988.

Carrot somatic embryogenesis is used extensively as a model system for early plant development (Sung et al. 1984; Nomura and Komanine 1986). A major advantage of this system is the relatively simple procedure with which massive amounts of somatic embryos can be produced under controlled conditions in liquid cultures. Somatic embryos of carrot closely resemble their zygotic counterparts from the 32-cell embryo onwards and pass through the successive stages of globular-, heart-, and torpedo-shaped embryos. In carrot cultures, somatic embryos develop exclusively from small clusters of cells, designated proembryogenic masses by Halperin (1966). The developing embryos frequently remain adhered to the proembryogenic masses by a suspensor-like group of cells (Street 1976). Proembryogenic masses consist of between 10 and 20 tightly adhering and densely cytoplasmic cells and are characteristic for all embryogenic carrot suspension cultures. To initiate somatic embryogenesis, it is sufficient to dilute suspension cultures, maintained at high cell density in the presence of the synthetic auxin 2,4-dichlorophenoxy acetic acid (2,4-D), approximately 100-fold in phytohormone-free basal medium. Cells that are similary diluted in medium containing 2,4-D continue to proliferate in an unorganized fashion.

Several approaches have been taken to identify genes 
that may be involved in the formation of somatic embryos. Comparison by two-dimensional polyacrylamide gel electrophoresis (PAGE) of the in vivo synthesized cellular proteins (Sung and Okimoto 1981, 1983; Choi and Sung 1984) as well as in vitro translation products (D.H. Wilde et al., in prep.; S.C. de Vries et al., in prep.) from somatic embyros and unorganized proliferating cells showed that the number of embryo-specific abundant proteins or in vitro products is remarkably small. One explanation for this finding is that somatic embryogenesis requires only minute changes in gene expression, not detectable with the methods used (Choi and Sung 1984). Alternatively, many of the genes responsible for embryo formation may already be expressed in proembryogenic masses during unorganized growth (Giuliano et al. 1984; Choi et al. 1987; D.H. Wilde et al., in prep.) and therefore will have escaped detection. The latter possibility is substantiated by the finding that virtually all cloned 'embryo-specific' genes obtained both by differential screening of cDNA libraries (Thomas and Wilde et al. 1985; D.H. Wilde et al., in prep.) or by immunoscreening (Choi et al. 1987) are already expressed at low levels in proembryogenic masses. In all cases, these genes are not expressed in nonembryonic cells and adult plant tissues. However, none of these genes has been analyzed in sufficient detail to define their possible function in somatic embryogenesis. Other genes, encoding $\alpha$ - and $\beta$-tubulin (Cyr et al. 1987) and extensin-1 (Thomas and Wilde 1987), were also shown to be more highly expressed in somatic embryos as compared with unorganized cells.

The role of conditioned medium during somatic embryogenesis has received very little attention. This is surprising since Halperin (1967) already noted the effects of cell interactions on the initiation of carrot somatic embryogenesis. Also Hari (1980) and Smith and Sung (1985) reported promoting effects of embryo-conditioned medium on the frequency of somatic embyrogenesis. No attempt was made in these studies to identify the responsible factors. Recently, Satoh et al. (1986) reported that a $65-\mathrm{kD}$ extracellular glycoprotein was well correlated with the presence of somatic embyros in carrot. Similarly, we described the promoting role of heat-labile, high molecular mass excreted cell factors on the formation of proembryogenic masses in newly initiated carrot suspension cultures (S.C. de Vries et al., in prep.).

We report here that, in contrast to the intracellular protein patterns, major changes occurs in the pattern of extracellular proteins during carrot somatic embryogenesis. These changes involve both increase and decrease of several glycosylated extracellular proteins during embryo development in a phytohormone-dependent fashion. Addition of embryo extracellular proteins to cell lines that are disturbed both in the correct synthesis of extracellular proteins and in embryo formation restore embryogenesis in these lines. Furthermore, we demonstrate that addition of the glycosylation inhibitor tunicamycin (Elbein 1987) results in partly glycosylated extracellular proteins and we confirm that tunicamycin simultaneously blocks somatic embryogenesis but not unorganized cell proliferation (LoSchiavo et al. 1986).
Since the tunicamycin-blocked embryo development is fully reversible by addition of embryo extracellular proteins we conclude that the presence of properly glycosylated extracellular proteins is an absolute requirement for the differentiation of carrot cells into somatic embryos.

To our knowledge, this is the first report that demonstrates the direct involvement of excreted high molecular weight polypeptides in early plant development.

\section{Results}

Extracellular proteins are developmentally regulated by auxins during somatic embryogenesis

Proembryogenic masses were purified from high density embryogenic suspension cultures of Daucus carota cv. Trophy-10, extensively washed in hormone-free medium, and inoculated at low cell density without 2,4-D. These embryo cultures produced large numbers of somatic embryos, reaching torpedo stage within 12 days. Proembryogenic masses cultured at low cell density with 2,4-D resulted in proliferating cells without any discernible embryo morphology (Fig. 1). Extracellular proteins produced during somatic embryogenesis and cell proliferation in the presence of $2,4-\mathrm{D}$ were labeled with ${ }^{35}$ S $]$ methionine at $2,5,9$, and 14 days after culture initiation and separated by SDS-PAGE. Equal amounts of hot trichloroacetic acid (TCA)-precipitable ${ }^{35}$ S material were applied to each lane. Comparing the extracellular proteins with $\left[{ }^{35} \mathrm{~S}\right]$ methionine-labeled intracellular proteins showed that no corresponding bands of the same intensity were present intracellularly. All the extracellular $\left[{ }^{35} \mathrm{~S}\right]$ methionine labeled material was sensitive to proteinase $\mathrm{K}$ (data not shown). These results indicate that the observed gel patterns are solely due to the labeling of extracellular protein material. The results presented in Figure 2 show that within 2 days after initiation of somatic embryogenesis, there is a substantial increase in the amount of 13-, 17-, and 29-kD extracellular proteins $(\mathrm{E})$ when compared with cells proliferating in the presence of 2,4-D (P). Between day 5 and 9, when the embryos have reached late heart stage, proteins of 13,38 , and $46 \mathrm{kD}$ now appear at higher concentrations in embryo media. Extracellular proteins of 21, 27, 36, 40, 44,48 , and $72 \mathrm{kD}$ that are present in 2,4-D-grown cultures have either disappeared or are strongly reduced in the medium of cultures producing somatic embryos (Fig. 2A).

${ }^{[35}$ S methionine labeling of the three sieved fractions containing single highly vacuolated cells ( $\$ 50 \mu \mathrm{m})$, proembryogenic masses $(50-125 \mu \mathrm{m})$, and large aggregates $(\geqslant 125 \mu \mathrm{m})$ after 6 days in B5 medium without 2,4-D revealed that all cells responded similarly to dilution and 2,4-D withdrawal. However, it is of interest to note (Fig. 2B) that the single-cell fraction, which did not produce somatic embryos, was more diffuse in the pattern of extracellular polypeptides. This is interpreted as being the result of a general response to 2,4-D withdrawal, i.e., 29-kD synthesis, followed (see also Fig. 2A) by the $46-$ and $38-\mathrm{kD}$ proteins once embryos have 
de Vries et al.

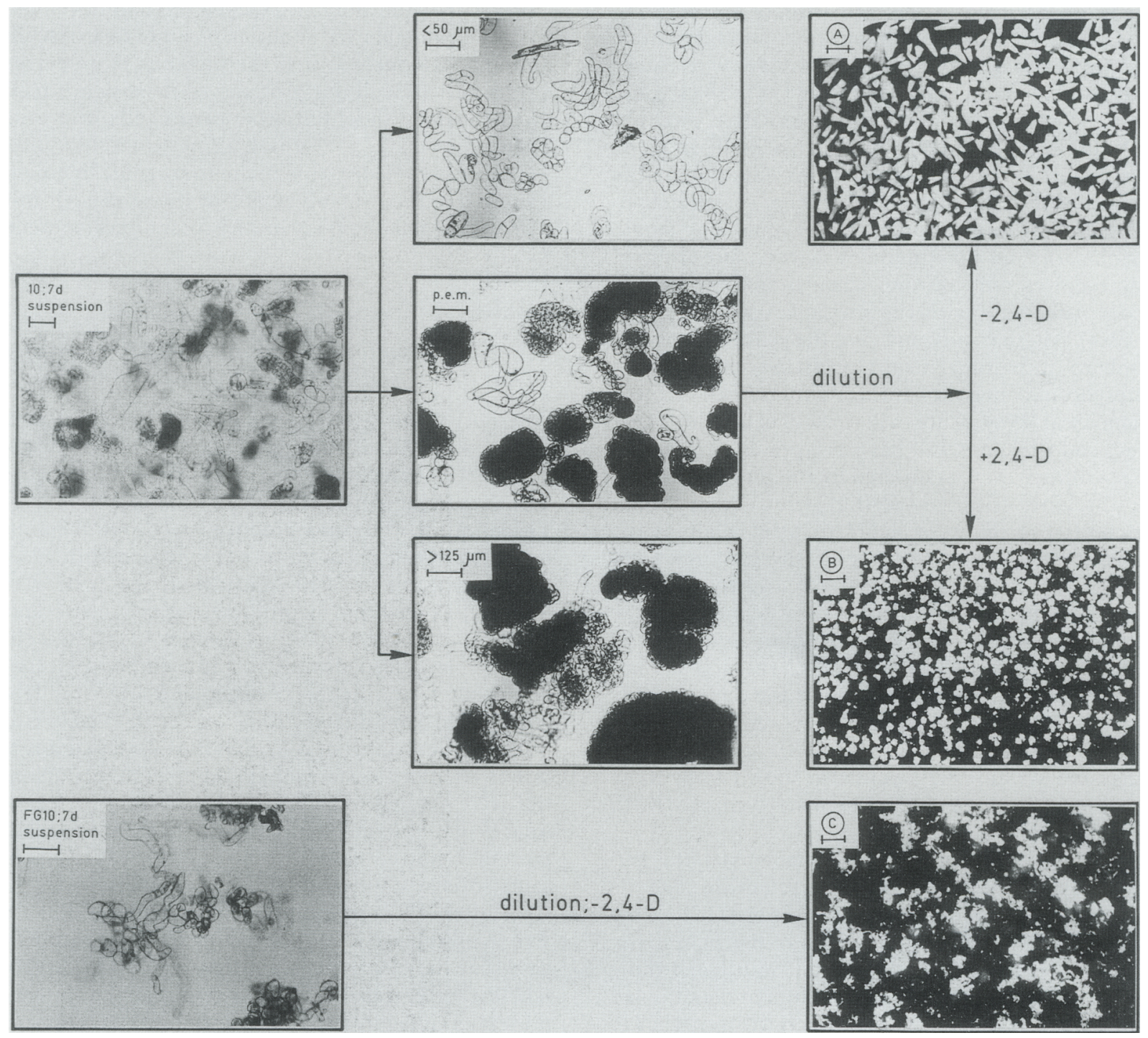

Figure 1. Fractionation of proembryogenic masses (p.e.m.) and morphology of the resulting embryos $(A)$ and proliferating cells $\langle B|$. Bar size is $100 \mu \mathrm{m}$. Bar size in $A, B$, and $C$ is $1 \mathrm{~mm}$. For comparison, a non-embryogenic suspension culture devoid of proembryogenic masses and the small microcalli derived from these cells when placed under conditions favoring embryogenesis are also shown $(C)$.

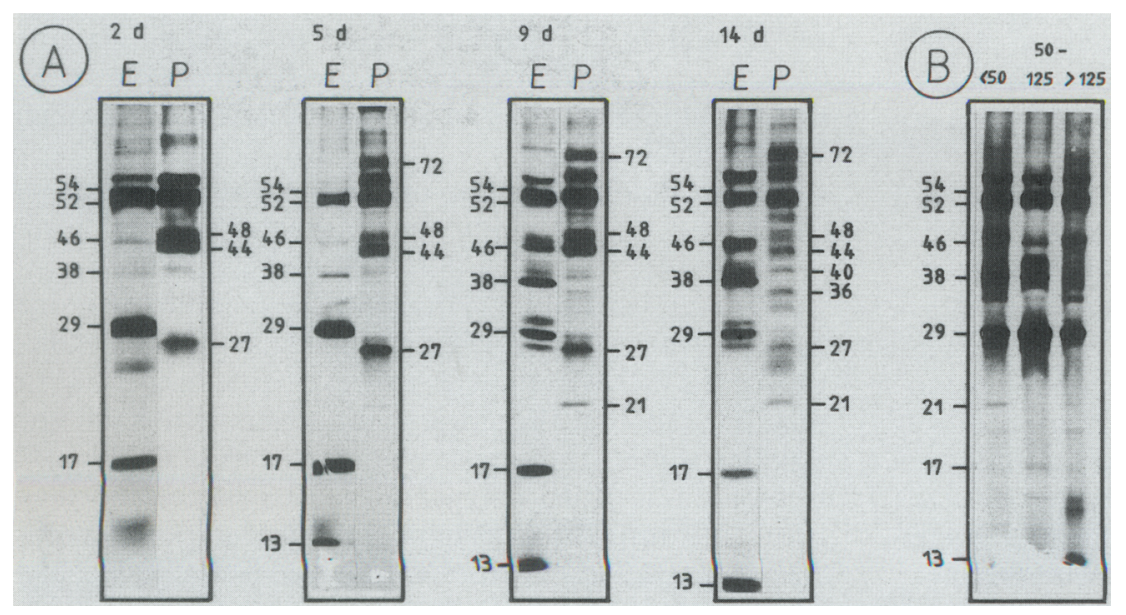

Figure 2. Fluorographs of $\left[{ }^{35} \mathrm{~S}\right] \mathrm{methio-}$ nine-labeled extracellular proteins. $(A)$ Proembryogenic masses were incubated with and without 2,4-D and labeled during $24 \mathrm{hr}$ at day $2,5,9$, and 14 after fractionation and dilution of the cells. (B) Sieve fractions labeled during $24 \mathrm{hr}$ at day 6 after fractionation and dilution in 2,4-D free medium. Relevant molecular masses were calculated from standard $\left[{ }^{14} \mathrm{C}\right]$ protein markers. 
formed. Some of the observed variation in extracellular proteins produced by somatic embryos can be explained by variation in the proembryogenic mass enrichment procedure that routinely resulted in beteen 10 and $50 \%$ pure proembryogenic masses. The observed variation in extracellular proteins is illustrated by the occasional presence of the 13- and 17-kD proteins in 2,4-D-grown cultures (see Fig. 4); also, they are not always prominently present in embryo cultures (compare Fig. 2A and B). On the other hand, the $21-\mathrm{kD}$ protein is also produced by the $\$ 50-\mu \mathrm{m}$ cell fraction in the absence of 2,4-D (Fig. 2B).

To verify whether other phytohormones exerted the same changes, proembryogenic masses were cultured at low cell density in various concentrations of 2,4-D, naphthalene acetic acid (NAA), and 6-benzylaminopurine (6-BAP). Medium proteins were labeled at day 6 after culture initiation and separated by SDS-PAGE /Fig. 3). The results show that addition of auxins 2,4-D and NAA had the same inhibitory effect on the synthesis of 13-, 17-, 29-, 38-, and possibly also the 46-kD extracellular proteins that are normally present during somatic embryogenesis. Proteins of 21 and $72 \mathrm{kD}$ appeared in the medium only in the presence of 2,4-D and not in the presence of NAA and 6-BAP.

Comparing the number of well-developed somatic embryos at the torpedo stage from these cultures as a function of the phytohormone concentration suggests a striking relationship between the presence of the 17-, $29-, 38-$, and $46-\mathrm{kD}$ proteins and eventual yield of somatic embryos. At the same time, it is clear that 2,4-D is a much more potent suppressor of embryogenesis than NAA, which is closely reflected in both the number of embryos obtained and the simultaneous suppression of embryo-related extracellular proteins. Addition of the cytokinin 6-BAP does not alter the embryo-like pattern to any great extent, except for the $38-\mathrm{kD}$ protein, which disappeared in cytokinin-grown cultures. Cultures grown in the presence 6-BAP yielded almost the normal amount of somatic embryos, but many were aberrantly formed and generally blocked before heart stage. This appears to be reflected in the almost normal pattern of embryo-related extracellular proteins, except for the $38-\mathrm{kD}$ protein. Pulse-chase experiments revealed that all extracellular proteins are stable for at least 1 week, both in the presence and absence of 2,4-D (data not shown).

\section{Non-embryogenic suspension cultures exhibit aberrant profiles of extracellular proteins}

Having established that embryogenic cells exhibit auxin-dependent changes in the pattern of extracellular proteins that appeared to be well correlated with somatic embryogenesis, we compared several cell lines with impaired potential to produce somatic embryos, both under conditions preventing embryogenesis (high and low cell density in the presence of 2,4-D) and under conditions suitable for embryogenesis to take place (low cell density without 2,4-D|. The nonembryogenic cell lines used were cv. Trophy-FG10, a line that had lost its regenerative potential after 2 years in culture, the $\alpha$ amanitin-resistant line $\alpha 5^{\text {II }}$ (Vergara et al. 1982), a line designated $\mathrm{C} 15$ containing both $\alpha$-amanitin and 8-azaguanine resistance (LoSchiavo et al. 1983), and the temperature-sensitive line ts l lc (LoSchiavo et al. 1985). Embryogenic cell lines used were cv. Trophy-10, cv. San Valery or $\mathrm{A}^{+}$, and $\alpha 5^{\mathrm{IIR}}$, a spontaneous embryogenic variant of $\alpha 5^{\text {II }}$. The labeled extracellular proteins of the various nonembryogenic lines compared with embryo-

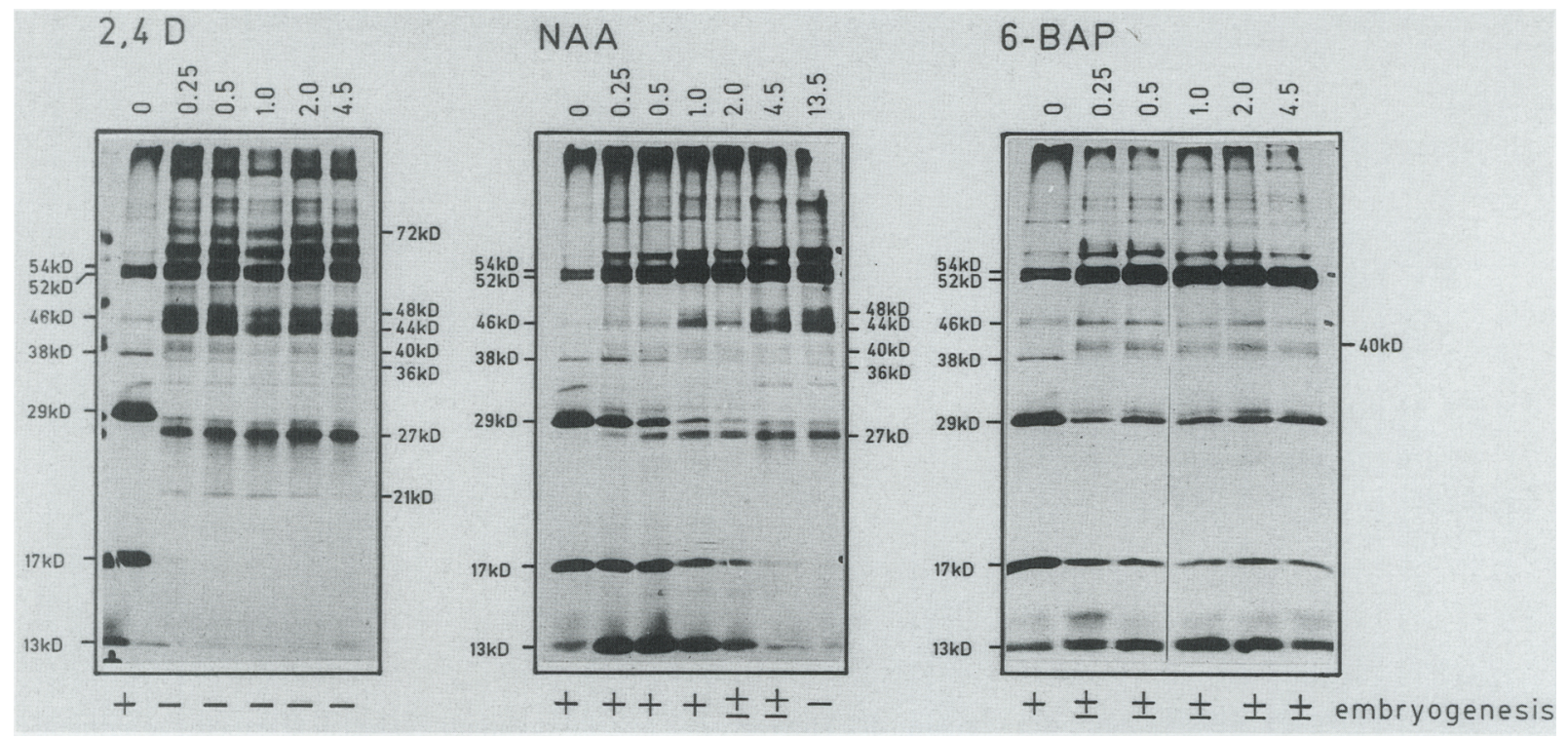

Figure 3. Fluorographs of $\left[{ }^{35} \mathrm{~S}\right]$ methionine-labeled extracellular proteins produced after culturing proembryogenic masses at low density in the presence of 2,4-D, NAA, and 6-BAP. Cultures were labeled for $24 \mathrm{hr} 5$ days after culture initiation. Production of somatic embryos from these cultures was scored at day 12 and indicated by + (large amount of well-developed somatic embryos), \pm (callused, aberrantly formed embryos), and - (no embryos, proliferating cells only). 
genic lines reveal striking alterations in all nonembryogenic lines tested under regenerative conditions. The differences range from the reduced concentration of the $38-\mathrm{kD}$ protein as in ts $11 \mathrm{c}$, the absence of the $46-\mathrm{kD}$ as in $\mathrm{Cl} 5$, and greatly reduced amounts of $29-, 38-$, and $46-\mathrm{kD}$ proteins as in $\alpha 5^{\mathrm{II}}$, to probably higher molecular mass forms of the 52/54-kD and 38-kD proteins in FG10 (Fig. 4). In the presence of 2,4-D the nonembryogenic cell lines showed only minor alterations in extracellular proteins when compared with embryogenic cell lines.

The finding that the nonembryogenic cell lines FG10 still responds by increased $29-\mathrm{kD}$ protein synthesis, while no embryos are formed, supports the previously made suggestion that there appears to be a rapid general change in extracellular proteins after dilution in hormone-free medium, followed by a more specific re- sponse, involving the 38 - and $46-\mathrm{kD}$ extracellular proteins.

Since none of the variant cell lines were developed with the object of establishing cell lines with impaired extracellular protein synthesis, it is noteworthy that all non- or low-embryogenic cell lines investigated show aberrations in their extracellular protein profiles, whereas embryogenic cell lines invariably exhibit the normal pattern. No cell lines were found in this initial survey of lines with impaired embryogenesis that maintained the normal pattern of extracellular proteins and yet failed to regenerate. Also, no cell lines were encountered that produced somatic embryos while exhibiting an aberrant profile of extracellular proteins. This suggests that the presence of several extracellular proteins is closely correlated with somatic embryogenesis.

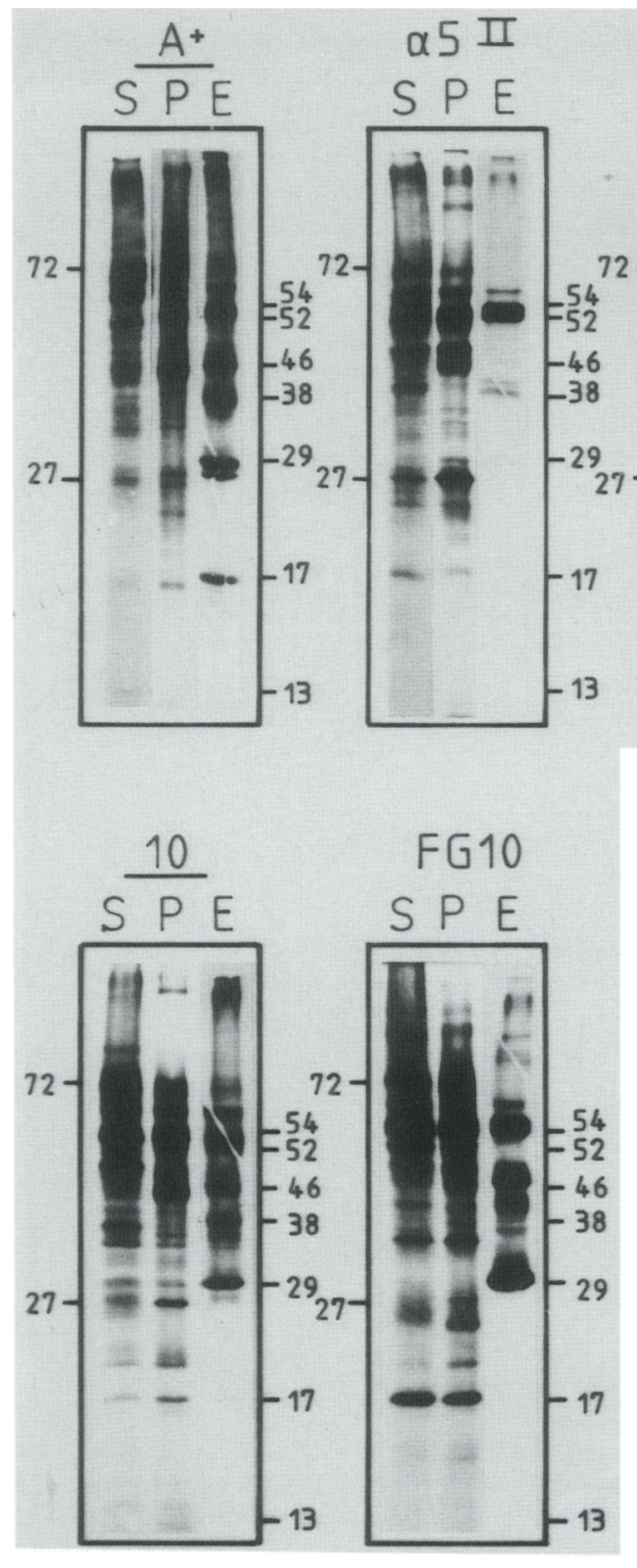

Figure 4. Fluorographs of $\left.{ }^{35} \mathrm{~S}\right]$ methionine-labeled extracellular proteins produced by high density suspension cultures $(S)$ and sieved fractions incubated at low density in the absence $(E)$ or presence $(P)$ of 2,4-D. Relevant molecular mass markers indicate the respective position of embryo extracellular proteins in regenerative cell lines. 
Several nonembryogenic variant lines can be complemented by addition of extracellular proteins produced by embryogenic cultures

Since there appeared to be a positive correlation between successful somatic embryogenesis and correct expression of several extracellular proteins during somatic embryogenesis, extracellular protein preparations of somatic embryos were tested for their ability to complement the non- or low-embryogenic cell lines. The results are summarized in Table 1 and indicate that cell lines $\alpha 5^{\mathrm{Il}}, \mathrm{c} 15$, and ts $11 \mathrm{c}$ respond positively to addition of extracellular proteins. It must be noted that the number of embryos obtained was never more than approximately $5 \%$ of the amount observed in embryogenic cultures. The complemented cultures of $\alpha 5^{\mathrm{II}}, \mathrm{cl} 5$, and ts $11 \mathrm{c}$ contained more proembryogenic masses and globular stage embryos when compared with the unsupplemented controls, indicating that at least the first stages in embryogenesis, the formation of proembryogenic masses, took place but that the added extracellular pro-

Table 1. Effect of the addition of extracellular proteins on somatic embryogenesis in several non-regenerative carrot cell lines

\begin{tabular}{|c|c|c|c|}
\hline Cell line & Characteristic & B5-0 & $\begin{array}{l}\text { B5-0 } \\
\text { with e.c.m. } \\
\text { concentrate }\end{array}$ \\
\hline 10 & embryogenic & + & + \\
\hline FG10 & $\begin{array}{l}\text { nonembryogenic, } \\
\text { no p.e.m.'s }\end{array}$ & - & $-{ }^{a}$ \\
\hline $\mathrm{A}^{+}$ & embryogenic & + & + \\
\hline$\alpha 5^{\mathrm{IIIR}}$ & $\begin{array}{l}\alpha \text {-amanitin } \\
\text { embryogenic }\end{array}$ & + & + \\
\hline$\alpha 5^{\mathrm{II}}$ & $\begin{array}{l}\alpha \text {-amanitin } \\
\text { nonembryogenic, } \\
\text { some p.e.m.'s }\end{array}$ & - & $+b$ \\
\hline $\mathrm{C} 15$ & $\begin{array}{l}\alpha \text {-amanitin }{ }^{\mathrm{r}}, 8 \text {-azaguanine }{ }^{\mathrm{r}} \\
\text { nonembryogenic, no p.e.m.'s }\end{array}$ & - & $++^{a}$ \\
\hline tsllc & $\begin{array}{l}\text { temperature sensitive, } \\
\text { nonembryogenic, } \\
\text { large aggregates }\end{array}$ & - & $+^{c}$ \\
\hline
\end{tabular}

All cultures were maintained and tested for embryogenic capability as described in Experimental procedures, except that somatic embryos were scored at day 30 after initiation.

(e.c.m.) Embryo conditioned medium.

a For embryogenesis to occur in C15 it was found that one and a half growth cycles (21 days) at high density in the presence of $2,4-\mathrm{D}$ and $50 \%$ cell-free unfractionated medium, preconditioned by an embryogenic suspension culture, was necessary to obtain some proembryogenic masses before the culture was assayed for embryogenic capability. A similar treatment on cell line FG10 failed to produce proembryogenic masses.

b Proembryogenic masses of cell line $\alpha 5^{\mathrm{II}}$ continued to proliferate in 2,4-D-free medium. To allow embryogenesis to take place, the cultures used to determine embryogenic capability were diluted weekly to the original level of $2 \times 10^{4}{\text { cells } \mathrm{ml}^{-1}}^{-1}$ using medium supplemented with embryo extracellular proteins.

${ }^{c}$ ts $11 \mathrm{c}$ was tested both under permissive $\left(24^{\circ} \mathrm{C}\right)$ and non-permissive $\left(32^{\circ} \mathrm{C}\right)$ temperatures. In both cases a stimulatory effect on embryogenesis was noted. teins could not completely restore somatic embryogenesis up to wild-type levels. Embryogenic cell lines did not respond at all to the added extracellular proteins and regenerated to the same level, both qualitatively and quantitatively, which suggests that once a particular level of embryogenic capability is attained it cannot be raised artificially by increasing the amount of extracellular proteins during embryogenesis.

Cell line FG10, the only culture that showed altered proteins rather than the absence of one or a few proteins, could not be complemented at all. Under no conditions were proembryogenic masses present in this line, indicating that prolonged growth in medium containing 2,4-D resulted in an irreversible block in embryogenic potential that could not be complemented by addition of the correct set of extracellular proteins.

\section{Glycosylation of extracellular proteins}

To characterize the extracellular proteins produced during embryogenesis, concanavalin A staining of Western-blotted proteins revealed that the 29-, 46-, and $52 / 54-\mathrm{kD}$ proteins contained high-mannose type sugars, whereas the $17-$ and $13-\mathrm{kD}$ proteins were unmodified. The $38-\mathrm{kD}$ protein appeared to be somewhat variable in this assay so it is not clear whether it is glycosylated or not (Fig. 5A). Labeling cultures with $\left[\gamma^{32} \mathrm{P}\right] \mathrm{ATP}$ showed that none of the proteins was phosphorylated (data not shown). Further evidence for the glycoprotein nature were the typical downward shifts in molecular mass observed when tunicamycin was added to regenerating cultures to prevent formation of $\mathrm{N}$-linked sugar chains. The reduction in molecular mass and simultaneous loss of concanavalin A staining showed that the 46- and $52 / 54-\mathrm{kD}$ proteins containing $\mathrm{N}$-linked sugars. The $29-\mathrm{kD}$ protein was not affected, which suggests that it contains O-linked sugars only. Increasing the concentration of tunicamycin resulted in degradation of the newly synthesized proteins except for the $29-\mathrm{kD}$ protein (data not shown). Tunicamycin treatment of cells proliferating in the presence of 2,4-D showed similar changes in extracellular proteins as observed in embryo cultures.

Employing deoxynojirimycin which interferes with sugar side chain processing, it was found that the 52/54$\mathrm{kD}$ extracellular proteins increased in molecular mass (Fig. 5B). This is in agreement with the reported action on protein glycosylation of this compound, the interference with high-mannose side chain trimming, resulting in proteins with longer unmodified sugar chains (Elbein 1987). The 46-, 38-, and 17-kD proteins were strongly reduced in concentration possibly due to interference with excretion. As with tunicamycin, the $29-\mathrm{kD}$ protein remained unaffected.

\section{Tunicamycin and deoxynojirimycin block somatic embryogenesis but not unorganized cell proliferation}

Since treatment of tunicamycin and deoxynojirimycin affected some of the extracellular proteins that were found to be increasingly expressed during somatic em- 
Figure 5. Effect of tunicamycin and deoxynojirimycin treatment on glycosylation of extracellular polypeptides by proembryogenic masses 5 days after fractionation and dilution. (A) Silver staining of embryo extracellular proteins 5 days after initiation in the absence or presence of $2 \mu \mathrm{g}$ $\mathrm{ml}^{-1}$ tunicamycin. Glycoproteins containing high-mannose type sugar side chains were detected with concanavalin A staining after blotting to nitrocellulose. (B) Fluorographs of $\left[{ }^{35} \mathrm{~S}\right]$ methionine-labeled extracellular polypeptides produced by 10 -day embryos $(E)$ and proliferating cells $(P)$ incubated with and without $2 \mu \mathrm{g}$ $\mathrm{ml}^{-1}$ of tunicamycin or $1 \mathrm{mM}$ of deoxynojiri$\operatorname{mycin}(C)$.

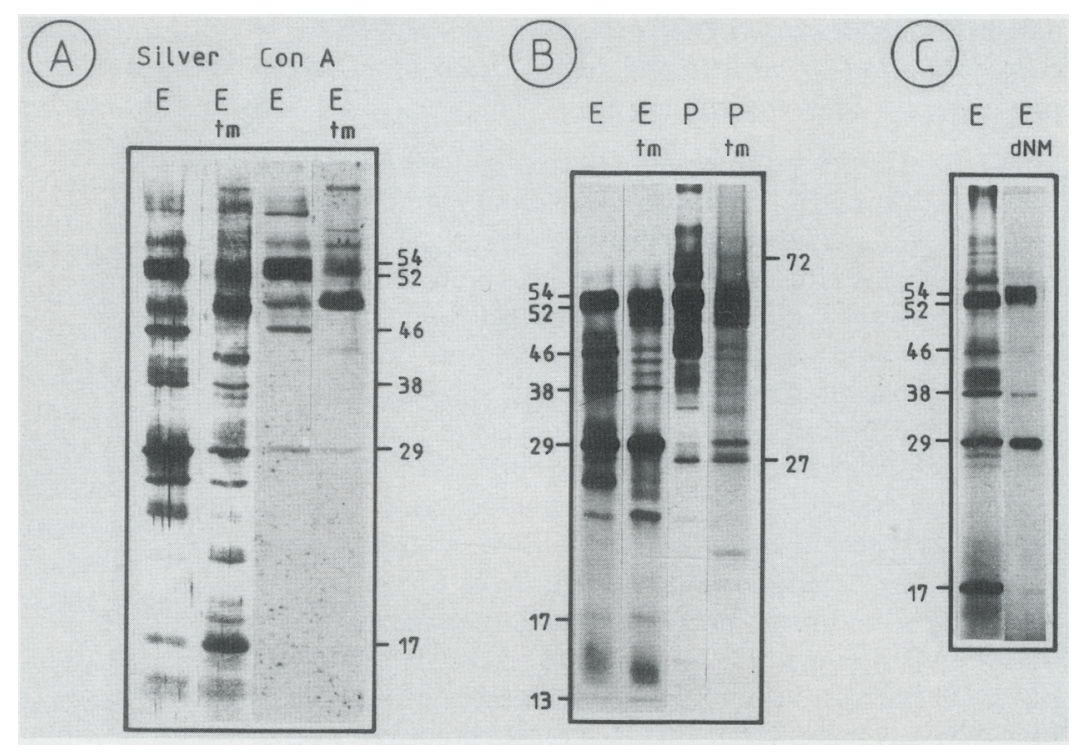

bryogenesis, the effects of these inhibitors on both somatic embryogenesis in the absence of $2,4-\mathrm{D}$ and cell proliferation in the presence of 2,4-D were investigated. Proembryogenic masses were isolated from embryogenic suspension cultures of cell line 10 and treated with both inhibitors. The results are summarized in Tables 2 and 3 and clearly show that somatic embryogenesis is completely blocked at a tunicamycin concentration of $2.5 \mu \mathrm{g}$ $\mathrm{ml}^{-1}$ and a deoxynojirimycin concentration of $1.0 \mu \mathrm{M}$, whereas unorganized proliferation of cells in medium containing 2,4-D is not affected. Since especially tunicamycin is known also to affect general metabolism in cells (Elbein 1987), viability of tunicamycin-treated cells was compared by three independent methods both in the absence and presence of 2,4-D (Table 3).

Although viability according to fluorescein diacetate (FDA)/Lisamin Green staining and $\left[{ }^{35} \mathrm{~S}\right]$ methionine incorporation showed a significant decrease after 5 days in the presence of tunicamycin, this decrease is not sufficient to be responsible for the complete lack of embryogenesis observed at these concentrations of the inhibitor. In addition, proliferating cells appear to be completely unaffected (Table 3). Microscopical analysis of tunicamycin-treated cultures without 2,4-D revealed that dead cells at day 5 were found almost exclusively on the surface of proembryogenic masses (data not shown). These results are interpreted with the assumption that when proembryogenic masses are placed under conditions that favor development of somatic embryos and that simultaneously block embryogenesis with tunicamycin, the cells in these masses simply stop growing, since the absence of 2,4-D prevents unorganized growth. However, when the first globular embryos appear in untreated cultures at day 2 after initiation, viability is still normal in the tunicamycin-treated cultures. Therefore, we conclude that tunicamycin specifically blocks development at the concentrations used, rather than interfering with metabolism in general.

Figure 6 shows that the effects of treating embryogenic masses with tunicamycin occur very early in somatic embryo development since these clusters of small, densely cytoplasmic cells are disrupted. Small clusters of highly vacuolated and single cells remain, which suggest that the normal close association of the cells in proembryogenic masses is destroyed. Since somatic embryos under the conditions used here develop exclusively from proembryogenic masses, interference with these clusters apparently leads to a complete block in

Table 2. Effect of tunicamycin $(t m ; A)$ and deoxynojirimycin $(d N M ; B)$ on somatic embryogenesis and cell proliferation of cell line 10

\begin{tabular}{lccccc}
\hline A $) \mathrm{tm}\left(\mu \mathrm{g} \mathrm{ml}^{-1}\right)$ & $\begin{array}{c}\text { Embryos } \\
-2,4-\mathrm{D}\end{array}$ & $\begin{array}{c}\text { Proliferating } \\
\text { cells, }+2,4-\mathrm{D}\end{array}$ & (B) dNM $(\mathrm{mm})$ & $\begin{array}{c}\text { Embryos } \\
-2,4-\mathrm{D}\end{array}$ & $\begin{array}{l}\text { Proliferating } \\
\text { cells, }+2,4-\mathrm{D}\end{array}$ \\
\hline 0.0 & 1.00 & 1.00 & 0.0 & 1.00 & 1.00 \\
1.0 & 0.92 & 1.03 & 0.2 & 0.80 & 1.00 \\
2.0 & $0.03-0.11$ & 1.53 & 0.4 & 0.85 & 1.20 \\
2.5 & $0.00-0.05$ & 0.89 & 0.6 & 0.22 & 1.43 \\
3.0 & 0.00 & 1.00 & 0.8 & 0.08 & 1.46 \\
4.0 & 0.00 & 0.68 & 1.0 & 0.00 & 1.07 \\
5.0 & 0.00 & 0.22 & 5.0 & 0.00 & 0.80 \\
10.0 & 0.00 & 0.24 & & & \\
\hline
\end{tabular}

Somatic embryos $(-2,4-\mathrm{D})$ and cell density in cells $\mathrm{ml}^{-1}$ were counted at day 14 after initiation and are presented as the fraction of untreated controls. 


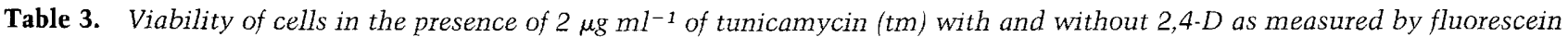
diacetate (FDA)/Lisamin green staining, $\left[{ }^{35} \mathrm{~S} / \mathrm{methionine} \mathrm{incorporation,} \mathrm{and} \mathrm{total} \mathrm{cell} \mathrm{counting}\right.$

\begin{tabular}{|c|c|c|c|c|c|c|}
\hline \multirow[b]{2}{*}{ Day } & \multicolumn{3}{|c|}{$\begin{array}{c}\text { Embryos } \\
-2,4-\mathrm{D}+\mathrm{tm}\end{array}$} & \multicolumn{3}{|c|}{$\begin{array}{l}\text { Proliferating cells } \\
\quad+2,4-\mathrm{D}+\mathrm{tm}\end{array}$} \\
\hline & $\begin{array}{l}\text { FDA/Lisamin } \\
\text { green }\end{array}$ & $\begin{array}{l}{\left[{ }^{35} \mathrm{~S}\right] \text { methionine }} \\
\text { incorporation }\end{array}$ & $\begin{array}{l}\text { cell } \\
\text { number }\end{array}$ & $\begin{array}{l}\text { FDA/Lisamin } \\
\text { green }\end{array}$ & $\begin{array}{l}{\left[{ }^{35} \mathrm{~S}\right] \text { methionine }} \\
\text { incorporation }\end{array}$ & $\begin{array}{l}\text { cell } \\
\text { number }\end{array}$ \\
\hline 2 & 0.99 & 2.40 & 1.03 & 0.97 & 1.47 & 1.19 \\
\hline 5 & 0.70 & 0.94 & 0.73 & 0.96 & 0.84 & 1.22 \\
\hline 14 & 0.56 & 0.60 & 0.87 & 0.95 & 1.56 & 1.09 \\
\hline
\end{tabular}

The results are presented as the fraction of parallel untreated controls. In the case of the embryo cultures, the cells not present in actual embryos were compared with FDA/Lisamin green and cell counting.

embryogenesis. In contrast, deoxynojirimycin treatment did not result in disruption of proembryogenic masses, but gave rise to abnormal callused embryos similar to those observed after growth in media containing cytokinin.

Addition of tunicamycin at a concentration of $2-3 \mu \mathrm{g}$ $\mathrm{ml}^{-1}$ to proembryogenic masses proliferating in the presence of 2,4-D resulted in a twofold reduction in the embryogenic potential (Table 4). This result indicates that the inhibition of embryogenesis by tunicamycin takes place at a very early stage, and can be accomplished already during unorganized growth. However,
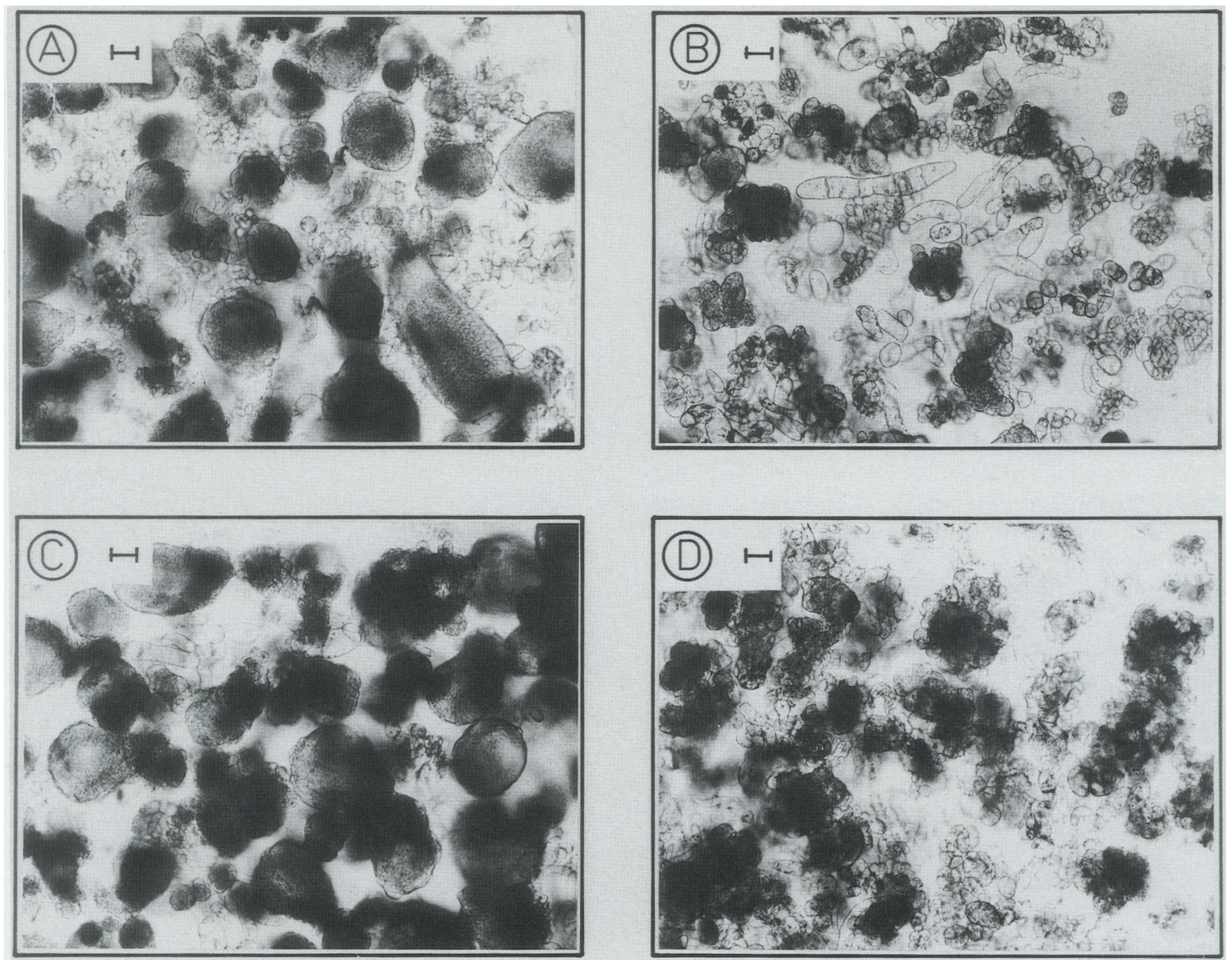

Figure 6. Morphology of proembryogenic masses after 5 days growth in 2,4-D-free medium. $(A)$ No addition. $(B) 2 \mu g \mathrm{ml}^{-1}$ tunicamycin. $(C) 2 \mu \mathrm{g} \mathrm{ml}^{-1}$ tunicamycin with $100 \%$ equivalence embryo extracellular proteins. $(D) 0.8 \mathrm{~mm}$ deoxynojirimycin. Bar indicates $48 \mu \mathrm{m}$. 
de Vries et al.

Table 4. Effect of tunicamycin on embryogenic potential of cell line 10

\begin{tabular}{lcc}
\hline Additions & $\begin{array}{l}\text { Proliferating } \\
\text { cells at day 14 }\end{array}$ & $\begin{array}{l}\text { Resulting embryos } \\
\text { after transfer to } \\
\text { B5-0, no tm }\end{array}$ \\
\hline 2,4-D & 1.00 & 1.00 \\
2,4-D; tm 1 $\mu \mathrm{g} \mathrm{ml}^{-1}$ & 1.05 & 1.29 \\
2,4-D; tm $2 \mu \mathrm{g} \mathrm{ml}^{-1}$ & 1.47 & 0.59 \\
2,4-D; tm $3 \mu \mathrm{g} \mathrm{ml}^{-1}$ & 1.46 & 0.47 \\
2,4-D; tm $4 \mu \mathrm{g} \mathrm{ml}^{-1}$ & 0.42 & 0.41 \\
\hline
\end{tabular}

Proembryogenic masses were first inoculated at $2 \times 10^{4}$ cells $\mathrm{ml}^{-1}$ in medium 2,4-D and again diluted to $2 \times 10^{4}$ cells $\mathrm{ml}^{-1}$ in hormone-free basal medium (B5-0) after 2 weeks of growth. Embryogenesis was scored 14 days after the second dilution. Cell numbers and embryos are presented as fraction of untreated controls.

the effect is not as striking as in embryo cultures, possibly due to the continuous formation of new proembryogenic masses in the presence of 2,4-D.

\section{Extracellular glycoproteins of embryogenic cultures restore somatic embryogenesis in tunicamycin-treated cultures but not in deoxynoiirimycin-treated cultures}

Treatment of proembryogenic masses with tunicamycin resulted in a complete block of somatic embryogenesis and simultaneously affected the glycosylation of several extracellular proteins. Therefore we asked whether the inhibitory effects of tunicamycin could be complemented by addition of conditioned media from untreated cultures. The results of these complementation experiments are summarized in Table 5 . A complementing activity was found in media conditioned by embryos at different stages of development with a broad optimum around day 8 after initiation, at which stage all embryorelated extracellular proteins are present. Surprisingly, unfractionated medium did not complement tunicamycin-blocked embryo cultures, and reconstitution of fractionated medium also failed to complement (Table $5 b)$. This phenomenon is not explained, but suggests that an as yet unidentified low molecular mass factor inhibits the activity of the added extracellular proteins.

A clear optimum concentration of the complementing activity is found between 50 and $100 \%$ of the amount of proteins normally present. Below $10 \%$ and over $500 \%$ of the amount of proteins normally present, the added concentrates could not restore proembryogenic mass integrity, while between 10 and $25 \%$ proembryogenic masses remained present, but failed to develop into embryos. This indicates that there is either a fairly well defined optimum concentration or a combination of both positive and negative activities (Table 5c). Control experiments given in Table $5 \mathrm{~d}$ indicate that the complementing activity is heat labile and proteinase $\mathrm{K}$ sensitive and is therefore a protein or proteins rather than excreted polysaccharides. To define the specificity of the complementing effect, several unrelated proteins, one of which (ovalbumin) is heavy glycosylated, were added ei- ther singly or simultaneously in various concentrations, but did not have a notable effect on the restoration of embryogenesis. During the growth of carrot cells in batch cultures, the medium $\mathrm{pH}$ usually rises from $\mathrm{pH}$ 5.5 (autoclaved fresh medium) to $\mathrm{pH} 7$. This $\mathrm{pH}$ change was found to be identical in untreated, tunicamycinblocked and tunicamycin-complemented cultures. Therefore nonspecific buffering of the media by polypeptides was not the factor responsible for the tunicamycin complementation (data not shown).

To calculate the amount of proteins necessary for complementation, the concentration of extracellular proteins was measured. During embryogenesis the medium contains approximately $0.8 \mu \mathrm{g}$ of total protein at day 10 . If all proteins were present in approximately the same amount, this is about $0.1 \mu \mathrm{g} \mathrm{ml}^{-1}$ per protein. Since, based on the tunicamycin complementation assay, these proteins are active between 50 and $100 \%$ of their normal level, this amounts to $1-3 \mathrm{~nm}$ for a $30-\mathrm{kD}$ protein.

Since tunicamycin treatment appeared to interfere with the integrity of the proembryogenic masses, while proembryogenic masses remained intact in complemented cultures, an extracellular protein or proteins necessary for the integrity of these structures should also be present in the media of high density 2,4-D-grown suspension cultures. Table $5 \mathrm{e}$ shows that the complementing effect can also be brought about by addition of Amicon concentrated suspension culture media, although the complementation is only about half of that found with embryo medium concentrates. Also, there appears to be a much sharper optimum; only addition at about $50 \%$ of the amount of protein found in suspension culture media gave a good complementing effect. Addition of $100 \%$ equivalence resulted in the presence of intact proembryogenic masses that did not develop further. Since the total amount of protein present in media of 7-day suspension cultures is about 4- to 5 -fold higher than in a 10-day embryo culture (data not shown), this indicates that the complementing activity is present at a 8- to 10-fold lower concentration in suspension culture media when compared with embryo media.

A well known effect of tunicamycin on glycoproteins is a reduction in protein resistance to proteolytic degradation after deglycosylation. Therefore the ability of several proteinase inhibitors was tested. Of these, only leupeptin and aprotinin were found to be able to restore embryogenesis in tunicamycin-blocked cultures. Recently Carlberg et al. (1987) purified a 13-kD trypsin inhibitor from media conditioned by embryogenic carrot cells. If this inhibitor is identical to the $13-\mathrm{kD}$ protein described here, part of the complementing activity could be due to addition of an endogenous proteinase inhibitor.

To exclude that complementation of tunicamycinblocked cultures was due to inactivation of tunicamycin by the added concentrates, $\left[{ }^{35} \mathrm{~S}\right]$ methionine labeling of extracellular proteins was performed in untreated controls, tunicamycin-blocked, and tunicamycin-complemented cultures, the latter supplied with leupeptin or 
Table 5. Complementation of tunicamycin-inhibited somatic embryogenesis

\begin{tabular}{|c|c|c|c|c|}
\hline \multicolumn{3}{|c|}{ Additions } & \multirow{2}{*}{$\frac{\begin{array}{l}\text { p.e.m. } \\
\text { integrity }\end{array}}{+}$} & \multirow{2}{*}{$\frac{\text { Embryos }}{1.00}$} \\
\hline$|a|-$ & & & & \\
\hline $\mathrm{tm}$ & & & - & 0.03 \\
\hline \multirow{7}{*}{ (b) $\begin{array}{l}\mathrm{t} \\
\mathrm{t} \\
\mathrm{t} \\
\mathrm{t} \\
\mathrm{t} \\
\mathrm{t} \\
\mathrm{t} \\
\mathrm{t}\end{array}$} & e.c.m. concentrate 3 days (p.e.m.--glob.) & eq. $50 \%$ & + & 0.64 \\
\hline & e.c.m. concentrate 6 days (glob.-heart) & eq. $50 \%$ & + & 1.09 \\
\hline & e.c.m. concentrate 8 days (heart-torp.) & eq. $50 \%$ & + & 1.23 \\
\hline & e.c.m. concentrate 10 days (torpedo) & eq. $50 \%$ & + & 1.18 \\
\hline & e.c.m. concentrate 14 days (torp.-plantlet) & eq. $50 \%$ & + & 0.90 \\
\hline & e.c.m. unfractionated 10 days & $50 \%$ & + & 0.03 \\
\hline & e.c.m. filtrate 10 days & $50 \%$ & - & 0.00 \\
\hline $\mathrm{tm}$ & e.c.m. filtrate + concentrate 10 days & $50 \%$ & + & 0.07 \\
\hline (c) $\mathrm{tm}$ & e.c.m. concentrate 10 days & eq. $1 \%$ & - & 0.00 \\
\hline \multirow{2}{*}{$\mathrm{tm}$} & e.c.m. concentrate 10 days & eq. $5 \%$ & - & 0.00 \\
\hline & e.c.m. concentrate 10 days & eq. $10 \%$ & + & 0.04 \\
\hline $\mathrm{tm}$ & e.c.m. concentrate 10 days & eq. $25 \%$ & + & 0.16 \\
\hline $\operatorname{tm}$ & e.c.m. concentrate 10 days & eq. $50 \%$ & + & 0.98 \\
\hline $\operatorname{tm}$ & e.c.m. concentrate 10 days & eq. $100 \%$ & + & 1.31 \\
\hline \multirow{2}{*}{$\begin{array}{l}\mathrm{tm} \\
\mathrm{tm}\end{array}$} & e.c.m. concentrate 10 days & eq. $200 \%$ & + & 0.59 \\
\hline & e.c.m. concentrate 10 days & eq. $500 \%$ & - & 0.02 \\
\hline (d) $\mathrm{tm}$ & e.c.m. concentrate 10 days, $20 \mathrm{~min} 100^{\circ} \mathrm{C}$ & eq. $100 \%$ & - & $0.00^{\mathrm{a}}$ \\
\hline $\mathrm{tm}$ & e.c.m. concentrate 10 days, $20 \mathrm{~min} 37^{\circ} \mathrm{C}$ & eq. $100 \%$ & + & $1.03^{\mathrm{a}}$ \\
\hline $\mathrm{tm}$ & e.c.m. concentrate 10 days, proteinase $\mathrm{K}$ & eq. $100 \%$ & - & $0.06^{\mathrm{b}}$ \\
\hline \multicolumn{2}{|r|}{ proteinase $\mathrm{K}$ only } & eq. $100 \%$ & + & $0.94^{\mathrm{b}}$ \\
\hline \multicolumn{2}{|r|}{ tm ovalbumin, BSA, Ldh $1-10 \mu \mathrm{g} \mathrm{ml}^{-1}$} & & - & $0.00-0.03$ \\
\hline $\operatorname{tm}$ & leupeptin $0.1-2.5 \mu \mathrm{g} \mathrm{ml}^{-1}$ & & + & $0.32^{\mathrm{c}}$ \\
\hline \multirow{2}{*}{$\mathrm{tm}$} & aprotinin $0.1-2.5 \mu \mathrm{g} \mathrm{ml}^{-1}$ & & + & $0.59^{\mathrm{c}}$ \\
\hline & s.c.m. concentrate 7 days & $1 \%$ & - & 0.00 \\
\hline (e) $\mathrm{tm}_{\mathrm{tm}}$ & s.c.m. concentrate 7 days & eq. $5 \%$ & - & 0.00 \\
\hline $\mathrm{tm}$ & s.c.m. concentrate 7 days & eq. $10 \%$ & - & 0.01 \\
\hline $\mathrm{tm}$ & s.c.m. concentrate 7 days & eq. $25 \%$ & + & 0.13 \\
\hline $\mathrm{tm}$ & s.c.m. concentrate 7 days & eq. $50 \%$ & + & 0.54 \\
\hline $\operatorname{tm}$ & s.c.m. concentrate 7 days & eq. $100 \%$ & + & 0.04 \\
\hline
\end{tabular}

The number of somatic embryos obtained after various additions is presented as the fraction of untreated controls. The effect of various additions on the integrity of the proembryogenic masses (p.e.m.) is noted by + when over $90 \%$ of the proembryogenic masses was intact and by - when less then $10 \%$ remained intact as compared to untreated controls. (tm) Tunicamycin; (e.c.m.) embryo-conditioned medium; (s.c.m.) suspension-culture-conditioned medium; (BSA) bovine serum albumin; (Ldh) lactate dehydrogenase. In (b) the differentiation state of the embryo cultures from which the conditioned medium was isolated is also shown. Additions of inhibitors and concentrates were all as described in Experimental procedures.

Addition of concentrates at 50 or $100 \%$ equivalence (eq.) means that the amount of protein was added that was normally present in untreated cultures of the same volume. Addition of filtrate and whole medium was at $50 \mathrm{or} 100 \% \mathrm{vol} / \mathrm{vol}$.

${ }^{a}$ Heating of e.c.m. concentrates was performed after dilution and filter sterilization of e.c.m. concentrates to avoid possible aggregates clogging the filters. Filter-sterilized medium rather than autoclaved medium was used in the heat inactivation experiments to avoid adverse effects due to heating the same medium twice.

b Samples of $0.1 \mathrm{ml}$ of concentrate containing $50 \mu \mathrm{g} \mathrm{ml}-1$ of proteinase $\mathrm{K}$ were incubated for $1 \mathrm{hr}$ at $37^{\circ} \mathrm{C}$, before 50 -fold dilution in $\mathrm{B} 5$ medium and filter sterilization. In the control experiment $0.1 \mathrm{ml}$ of proteinase $\mathrm{K}$ in $\mathrm{B} 5$ medium was diluted 50 -fold, filter sterilized, and added to the cells. Employing less than $50 \mu \mathrm{g} \mathrm{ml}-1$ of proteinase $\mathrm{K}$ resulted in partial degradation of extracellular proteins only, verified by SDS-PAGE, and also resulted in partial restoration of embryogenesis.

c The complementing effects from a culture with $1 \mu \mathrm{g} \mathrm{ml}^{-1}$ of each protease inhibitor is given. Raising the inhibitor concentration did not result in more somatic embryos.

active and heat-inactivated embryo extracellular proteins. The results shown in Figure 7 clearly indicate that tunicamycin remained active in complemented cultures as well as in blocked cultures. The observed complementing effects are therefore due to the activity of the added proteins and not the result of inhibitor inactivation.

Inspection of Figure 7 reveals that the proteins most likely to be responsible for complementation are the 46and $52 / 54-\mathrm{kD}$ proteins, since these are predominantly deglycosylated in the tunicamycin-treated cultures. The
17-, 29-, and 38-kD proteins are apparently not affected (compare also Fig. 6B). Another effect was that the $13-\mathrm{kD}$ protein is present at reduced concentration in the tunicamycin-treated cultures, probably due to proteolytic degradation. Since the $13-\mathrm{kD}$ protein is again present in the complemented cultures this may indicate that altered protein stability could be a factor in the complementation assay.

Table 6 summarizes the attempts to complement deoxynojirimycin-blocked cultures. Although deoxynojirimycin did leave the proembryogenic masses intact, 


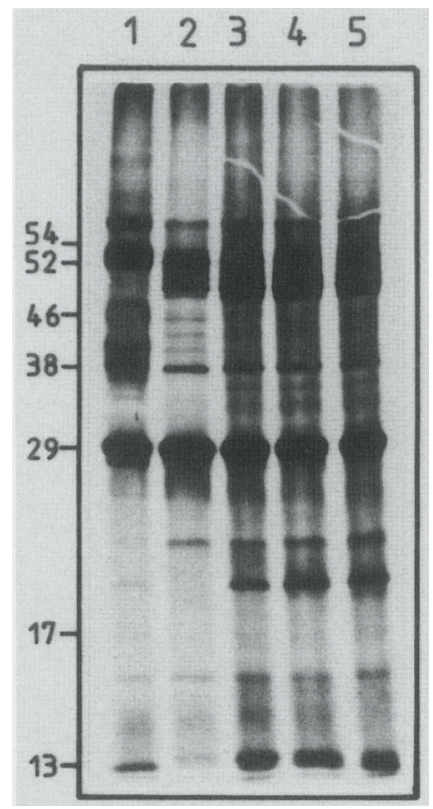

Figure 7. Fluorographs of $\left.{ }^{35} \mathrm{~S}\right]$ methionine-labeled extracellular proteins produced by proembryogenic masses 9 days after initiation without (1) and with (2) $2 \mu \mathrm{g} \mathrm{ml}^{-1}$ of tunicamycin, and with $2 \mu \mathrm{g} \mathrm{ml}^{-1}$ of tunicamycin including active embryoextracellular proteins $\{3\}$, heat-inactivated extracellular proteins (4), and the protease inhibitor leupeptin (5). Embryos were present only in cultures 1,3 , and 5 .

the inhibition of embryogenesis appeared to be irreversible under the conditions tested. Since only the 52/54$\mathrm{kD}$ and possibly also the $46-\mathrm{kD}$ proteins are increased in molecular mass after deoxynojirimycin treatment, this raises the interesting possibility that the correctly processed sugar side chains on these proteins are of crucial importance for their action. It is tempting to speculate that a similar alteration in the apparent molecular mass of the 52- and $54-\mathrm{kD}$ proteins has taken place in the non-embryogenic cell line FG10 (Fig. 4), that also could not be complemented. This could point to an interference with sugar side chain trimming reactions of these extracellular proteins after prolonged culture in the presence of 2,4-D.

Concentrated media of cell lines producing altered patterns of extracellular proteins under regenerative conditions (Fig. 4) were tested for their ability to complement tunicamycin-blocked cultures. The results shown in Table 7 indicate that extracellular proteins from embryogenic lines could all complement tunicamycin inhibition, although with different efficiencies. Extracellular proteins from the nonembryogenic lines $\mathrm{C} 15$ and $\alpha 5^{\mathrm{II}}$ could maintain integrity of the proembryogenic masses in the presence of tunicamycin but did not allow further development. In contrast, extracellular proteins from the only cell line that produced proteins with altered molecular masses were totally inactive in complementing the inhibition of embryogenesis by tunicamycin. Therefore, since both $\mathrm{C} 15$ and $\alpha 5^{\text {II }}$ cell lines produced normal $52 / 54-\mathrm{kD}$ species, we conclude that these proteins, which are apparently dependent on their
Table 6. Complementation of deoxynojirimycin-inhibited somatic embryogenesis

\begin{tabular}{|c|c|c|}
\hline Additions & $\begin{array}{l}\text { p.e.m. } \\
\text { integrity }\end{array}$ & Embryos \\
\hline - & + & 1.00 \\
\hline $\mathrm{dNM} 0.8 \mathrm{mM}$ & + & 0.10 \\
\hline $\begin{array}{l}\text { dNM } 0.8 \mathrm{~mm} \text { e.c.m. } \\
\text { concentrate } 10 \text { days eq. } 50 \%\end{array}$ & + & 0.07 \\
\hline $\begin{array}{l}\text { dNM } 0.8 \mathrm{~mm} \text { e.c.m. } \\
\text { concentrate } 10 \text { days eq. } 100 \%\end{array}$ & + & 0.04 \\
\hline $\mathrm{dNM} 1.0 \mathrm{~mm}$ & + & 0.00 \\
\hline $\begin{array}{l}\text { dNM } 1.0 \mathrm{~mm} \text { e.c.m. } \\
\text { concentrate } 10 \text { days eq. } 50 \%\end{array}$ & + & 0.00 \\
\hline $\begin{array}{l}\text { dNM } 1.0 \text { mM e.c.m. } \\
\text { concentrate } 10 \text { days eq. } 100 \%\end{array}$ & + & 0.00 \\
\hline
\end{tabular}

Presentation of data and abbreviations used are given in the legend of Table 5.

(dNM) Deoxynojirimycin.

sugar moiety for proper activity, are involved in the maintenance of integrity of proembryogenic masses. This is in accordance with the finding that the 52- and $54-\mathrm{kD}$ proteins are present in all media tested, regardless of the differentiation state of the cells. Other proteins such as the 38 - and $46-\mathrm{kD}$ proteins could be active at later stages of somatic embyro development.

\section{Discussion}

In this work we have presented evidence that several glycosylated extracellular proteins appear to be essential for the differentiation of carrot suspension cells into so-

Table 7. Complementation of tunicamycin-inhibited somatic embryogenesis by embryo medium concentrates from cell lines with impaired embryogenic capability

\begin{tabular}{|c|c|c|}
\hline Additions & $\begin{array}{l}\text { p.e.m. } \\
\text { integrity }\end{array}$ & Embryos \\
\hline $\begin{array}{l}\text { tm e.c.m. concentrate } 10 \\
10 \text { days eq. } 100 \%\end{array}$ & + & 1.06 \\
\hline $\begin{array}{l}\text { tm e.c.m. concentrate FG } 10 \\
10 \text { days eq. } 100 \%\end{array}$ & - & 0.00 \\
\hline $\begin{array}{l}\text { tm e.c.m. concentrate } A^{+} \\
10 \text { days eq. } 100 \%\end{array}$ & + & 0.73 \\
\hline $\begin{array}{l}\text { tm e.c.m. concentrate } \alpha 5^{\text {IIIR }} \\
10 \text { days eq. } 100 \%\end{array}$ & + & 0.63 \\
\hline $\begin{array}{l}\text { tm e.c.m. concentrate } \alpha 5^{\mathrm{II}} \\
10 \text { days eq. } 100 \%\end{array}$ & + & 0.07 \\
\hline $\begin{array}{l}\mathrm{tm} \text { e.c.m. concentrate C15 } \\
10 \text { days eq. } 100 \%\end{array}$ & + & 0.01 \\
\hline
\end{tabular}

E.c.m. refers to preparations obtained from cultures treated identical to embryogenic cultures, regardless of whether embryos were formed or not. Addition was at $100 \%$ equivalence of the amount of protein found in the lines with impaired embryogenesis. Addition at $100 \%$ equivalence of the amount found in embryogenic cultures did not result in significantly greater complementation (data not shown). Abbreviations and presentation of results are as described in the legend of Table 5. 
matic embryos under in vitro conditions. At present we can only speculate on the exact role of these proteins in the process of somatic embryogenesis. However, several possibilities for their action can be inferred from the data presented.

Since the carrot cultures used in this work are able to grow well without added cytokinin, endogenous cytokinin production is apparently sufficient to sustain not only 2,4-D-induced unorganized proliferation, but also embryogenesis. Consequently, the extracellular proteins do not show major changes after cytokinin addition to proembryogenic masses, except for the $38-\mathrm{kD}$ protein. In contrast, addition of auxins results in major alterations in extracellular proteins in a concentration- and auxintype-dependent way. This suggests that the presence of a particular set of extracellular proteins is carefully controlled by the balance of auxin and cytokinin, and this is more or less what one would expect for a set of phytohormone-controlled proteins involved in plant development. The proteins described here could therefore represent a specific developmental response to a more general phytohormone signal. Clearly, phytohormones affect many more developmental processes besides extracellular proteins, indicated by the fact that proembryogenic masses in the presence of auxins could not be induced to form somatic embyros after addition of embryo-derived extracellular proteins (S.C. de Vries, unpubl.). One way to control developmentally important proteins once outside the cell, is by a control mechanism employing specific proteases. These proteases in turn could then be controlled by protease inhibitors, thus offering a control system by specific proteolytic inactivation/activation or by turnover rate of developmentally active proteins. Carlberg et al. (1984) failed to detect significant extracellular proteolytic activity in carrot cell media by means of chromogenic peptides. However, this could have been due to the use of unfractionated medium preparations. Carlberg et al. (1987) purified a trypsin inhibitor from conditioned carrot somatic embryo media, and if the results of the successful tunicamycin inhibition/complementation experiment described here is taken into account, this could reflect a control mechanism of extracellular proteins by means of proteolytic activity.

The concentrations in which the described proteins appear to be active are about three orders of magnitude lower than the concentrations in which phytohormones are generally used and are about equal to the lower end of the concentration range reported for oligosaccharins (Tran Thanh Van 1985). The extracellular proteins therefore appear to be active in somatic embryogenesis at concentrations well within the working range of animal cell growth factors. However, at present it is difficult to envisage a model whereby a growth-factor-like polypeptide could interact directly with specific membrane receptors because of the presence of the cell wall.

Based on the complementing ability up to proembryogenic masses in the tunicamycin assay of extracellular protein preparations derived from cell lines $\alpha 5^{\text {II }}$ that produced essentially only the $52 / 54-\mathrm{kD}$ doublet, we propose that the $52 / 54-\mathrm{kD}$ extracellular proteins are involved with integrity of the proembryogenic masses. Clearly, these proteins alone are insufficient for completed somatic embryogenesis, since only extracellular protein preparations from embryogenic suspension cultures and actual embryo cultures can fully complement tunicamycin inhibition. This is supported by the fact that not all the nonembryogenic cell lines that could be complemented are deficient in the same extracellular protein. The role of the $29-\mathrm{kD}$ protein that appears very soon after 2,4-D withdrawal remains unclear. This protein is always present in embryo cultures but is also produced by nonembryogenic cells in the absence of $2,4-\mathrm{D}$, so its presence seems correlated with phytohormone removal rather than embryogenesis. Apparently several different extracellular proteins, i.e., the $29-, 38-$, and $46-\mathrm{kD}$ proteins, have to be present in a particular concentration and possibly in a sequential fashion to complete embryo development. Of these, only the $46-\mathrm{kD}$ protein is suppressed by auxin, affected by tunicamycin, and absent or reduced in some nonembryogenic cell lines. Therefore, this protein is a likely candidate for an extracellular protein directly involved in somatic embryogenesis.

The role of extracellular proteins in animal cell differentiation is very well established and will be reviewed here only briefly. Many cell-type-specific growth factors controlling cell division, and their receptors, have been described (James and Bradshaw 1984). In addition, much attention has been focused recently on the identification of cell-type-specific adhesion proteins, called cadherins (Takeichi 1987) and extracellular matrix proteins, e.g., fibronectin (McDonagh 1985), the corresponding receptors (Pytela et al. 1985), and transmembrane anchoring molecules (Tamkum et al. 1986). Cadherins are implicated in playing decisive roles in animal development by being one of the mechanisms for cell-cell recognition and subsequent interaction (Takeichi 1987). Whether analogous recognition mechanisms exist in plants has not been established. The stylar glycoprotein genes described by Anderson et al. (1986) are the only detailed example of a cell-cell recognition mechanism operative in higher plants.

The differentiation of plant cells however is generally assumed to be controlled by phytohormones. Despite considerable research following the classical experiments of Skoog and Miller (1957), who demonstrated that organogenesis in tobacco pith callus could be controlled by varying the auxin/cytokinin ratio in the medium, the molecular mechanisms by which phytohormones control plant cell differentiation remain largely unknown (Trewavas and Cleland 1983; Vanderhoef and Kosuge 1984). Several genes have been isolated that appear to be regulated by auxins (Theologis 1986). Few of these have been identified and were shown to encode hydrolytic enzymes such as $\beta$ 1,3-glucanase (Mohnen et al. 1985|, for which the natural substrates are probably found in the plant cell wall matrix, and pathogenesis-related proteins (Memelink et al. 1987). Although the pleiotropic effects of most phytohormones must be taken into account when interpreting these results, it is interesting to note that auxins and cytokinins appar- 
ently directly affect expression of genes encoding enzymes presumably involved in cell wall metabolism (Fry 1985,1986 ). Another group of lytic enzymes that can affect cell wall structure are peroxidases, of which several specific isozymes appear well corelated with tobacco organogenesis (Kay and Basile 1987). Recently there is a growing interest in the role of auxin-regulated cell wall associated proteins (O'Neill and Scott 1987). Despite the fact that plant cell walls contain, in addition to complex polysaccharides, hundreds of different proteins, glycoproteins (Roberts et al. 1985), and proteoglycans (McNeil et al. 1984), only the cell wall glycoprotein extensin has been cloned and studied in detail (Stafstrom and Staehelin 1987; Tierney and Varner 1987). So far, no definite conclusion has yet been reached on its possible function. In addition, evidence has been put forward that small oligosaccharide fragments released from plant cell walls (Darvill et al. 1985) are active in various physiological processes such as cell division (Binns et al. 1987) and plant morphogenesis (Tran Thanh Van 1985). Taken together, the phytohormone-mediated expression of genes encoding enzymes involved in cell wall metabolism could be an important factor in plant cell differentiation.

Common enzymatic activities frequently encountered in plant media are usually hydrolytic enzymes (Akazawa and Hara-Nishimura 1985), such as peroxidases (Van Huystee 1987), phosphatases (Giarrocchi et al. 1981), proteases (Wink 1984), and a protease inhibitor (Carlberg et al. 1987). However, the significance of the presence of these lytic enzyme activities in plant cell media is poorly understood.

Although the identity and exact role of the extracellular proteins described in this work remain to be determined, it is clear that with the aid of carrot cell lines impaired in somatic embryogenesis, together with the tunicamycin inhibition/complementation assay, an experimental system has been developed that will allow a straightforward analysis of the function of extracellular proteins in early plant development.

\section{Experimental procedures}

Plant material and culture conditions

Daucus carota cv. 'Flakkese' SG766 Trophy seeds, generously supplied by Zaadunie B.V., Enkhuizen, The Netherlands, were used as the starting material to establish embryogenic suspension cultures designated as cultivar no. 10 (S.C. de Vries et al., in prep.). High density suspension cultures of this cultivar were maintained on a gyrotory shaker at $100 \mathrm{rpm}$, at $25^{\circ} \mathrm{C}$ and an 18-hr light period in liquid B5 medium (Gamborg et al. 1968) with $2 \mu \mathrm{M} 2,4-\mathrm{D}$ at a 14-day subculture cycle by inoculating 2 $\mathrm{ml}$ of packed cell volume in $50 \mathrm{ml}$ of medium, corresponding to an initial cell density of approximately $10^{6}$ cells $\mathrm{ml}^{-1}$. All other cell lines derived from $D$. carota cv. 'San Valery,' designated $\mathrm{A}^{+}, \alpha 5^{\mathrm{II}}, \alpha 5^{\mathrm{IIR}}, \mathrm{cl} 5$, and ts $11 \mathrm{c}$ were maintained similarly but in B5 medium with $2.3 \mu \mathrm{M}$ of $2,4-\mathrm{D}$ and $1.15 \mu \mathrm{M}$ of 6-BAP.

For initiation of embryogenesis, high density suspension cells from cultures 7 days after transfer were size fractionated be tween 125 and $50 \mu \mathrm{m}$ nylon meshes. This fraction was purified further by a slow rotating motion in large $13-\mathrm{cm}$-diameter petri dishes in 2,4-D-free B5 medium. After several of these density separations, proembryogenic masses were collected from the middle of the dish, the cell density was determined by the chromic acid dispersion method (Sung 1976), and the proembryogenic masses were suspended at a density of $2 \times 10^{4}$ cells $\mathrm{ml}^{-1}$ in either 2,4-D-free B5 medium yielding somatic embryos or in B5 medium with phytohormones yielding low-density proliferating cultures.

\section{$\left[{ }^{35}\right.$ S]methionine labeling of extracellular proteins}

Aliquots of $1 \mathrm{ml}$ of cells were withdrawn from cultures, transferred to $25-\mathrm{ml}$ round-bottom tubes (Nunc Inc.), and cultured for $24 \mathrm{hr}$ at $120 \mathrm{rpm}$ on a gyrotory shaker at $25^{\circ} \mathrm{C}$ and an $18-\mathrm{hr}$ light period in the presence of $20 \mu \mathrm{Ci}$ of ${ }^{35}$ S ]methionine (Amersham). After labeling, cells were removed by centrifugation for $5 \mathrm{~min}$ at $8000 \mathrm{~g}$.

The labeled medium proteins were precipitated by addition of 2.5 volumes of ethanol at $4^{\circ} \mathrm{C}$, collected by centrifugation for $30 \mathrm{~min}$ at $10,000 \mathrm{~g}$, washed with ethanol, and resuspended in SDS-PAGE sample buffer. Incorporation was determined as hot TCA-insoluble material. Pilot experiments employing $0.22-\mu \mathrm{m}$ filtrated medium and microscopical examination of the media after centrifugation showed that the labeled medium proteins obtained this way were completely devoid of proteins from residual cells. Electrophoresis of the labeled proteins was then performed on $12.5 \%$ SDS-PAGE.

\section{Preparation of extracellular proteins}

Extracellular proteins from high-density suspension cultures at day 7 after transfer and embryo and proliferating cultures at day 10 were harvested by centrifuging cultures at $400 \mathrm{~g}$. The resulting cell-free medium was then passed through a Whatman $1 \mu \mathrm{M}$ filter and a $0.22-\mu \mathrm{m}$ filter (Millipore), concentrated 100- to 200 -fold by Amicon pressure dialysis using Amicon YM5000 membranes at $5-\mathrm{kD}$ cut-off, and stored at $-80^{\circ} \mathrm{C}$. The amount of protein present in the concentrates was determined by the Bio-Rad assay and verified by SDS-PAGE and Coomassie staining. Extracellular protein samples were analyzed by silver staining (Morrisey 1981), and glycoproteins were detected after electroblotting on nitrocellulose followed by concanavalin A staining (Faye and Chrispeels 1985). Protein blots were stained for protein using Aurodye (Janssen Pharmaceuticals).

\section{Tunicamycin and deoxynoirimycin inhibition/ complementation assay}

Tunicamycin (Sigma) was used without further purification and dissolved at $2 \mathrm{mg} \mathrm{ml}^{-1}$ in $10 \mathrm{~mm}$ sodium phosphate $(\mathrm{pH} 10.5)$. Deoxynojirimycin, a generous gift of Dr. W. Truscheit (Bayer AG., FRG), was dissolved at $100 \mathrm{~mm}$ in distilled water. Before use, the appropriate amounts of inhibitors were diluted in B5 medium, sterilized through $0.22-\mu \mathrm{m}$ filters /Schleicher and Schull), and added to an equal volume of B5 medium containing proembryogenic masses. Extracellular protein concentrates were diluted in B5 medium to the desired final concentration and filter sterilized together with the inhibitors before addition to an equal volume of B5 medium with proembryogenic masses. Pilot experiments with labeled and unlabeled extracellular proteins showed that over $90 \%$ of the concentrated proteins was passed through the $0.22-\mu \mathrm{m}$ filters and that no specific loss of any proteins occurred. All inhibition/complementation assays were performed in duplicate in $2 \times 10 \mathrm{ml}$ (final volume) shaking cultures and $2 \times 5 \mathrm{ml}$ (final volume) stationary cultures in petri dishes. Embryogenesis and proembryogenic mass integrity were scored at 3,6 , and 12 days after cul- 
ture initiation. Unless noted, only the results at day 12 are given.

\section{Acknowledgments}

We thank Oliver Richards and Fred van Engelen for critical reading of the manuscript, Piet Madern for art work and photography, Hedy Adriaansz and Marie-José van Neerven for typing the manuscript, and Martin van Spanje and Anja Everink for skillful technical assistance in initial experiments. This work was supported in part by a grant of the Commission of the European Communities to S.C. de V. and M.T.

\section{References}

Akazawa, T. and I. Hara-Nishimura. 1985. Topographic aspects of biosynthesis, extracellular secretion, and intracellular storage of proteins in plant cells. Annu. Rev. Plant Physiol. 36: $441-472$.

Anderson, M.A., E.C. Cornish, S.L. Mau, R. Hoggart, A. Atkinson, I. Bonig, E.G. Williams, B. Grego, R. Simpson, P. Roche, J. Haley, J. Penschow, H. Niall, G. Tregear, R. Crawford, J. Coghlan, and A.E. Clarke. 1986. Cloning of cDNA for a stylar glycoprotein associated with expression of self-incompatability in Nicotiana alata. Nature 321: 38-44.

Binns, A.N., R.H. Chen, H.N. Wood, and D.G. Lynn. 1987. Cell division promoting activity of naturally occurring dehydrodiconiferyl glycosides: Do cell wall components control cell division? Proc. Natl. Acad. Sci. 84: 980-984.

Carlberg, I., K. Söderhäll, K. Glimelius, and T. Eriksson. 1984. Protease activities in non-embryogenic and embryogenic carrot cell strains during callus growth and embryo formation. Physiol. Plant 62: 458-464.

Carlberg, I., L. Jonsson, A. Bergenstrahle, and K. Söderhäll. 1987. Purification of a trypsin inhibitor secreted by embryogenic carrot cells. Plant Physiol. 84: 197-200.

Choi, J.H. and Z.R. Sung. 1984. Two-dimensional gel analysis of carrot somatic embryogenic proteins. Plant Mol. Biol. Reporter 2: 19-25.

Choi, J.H., L.-S. Lui, C. Borkird, and Z.R. Sung. 1987. Cloning of genes developmentally regulated during plant embryogenesis. Proc. Natl. Acad. Sci. 84: 1906-1910.

Cyr, R.J., M.M. Bustos, M.J. Guiltinan, and D.E. Fosket. 1987. Developmental modulation of tubulin protein and mRNA levels during somatic embryogenesis in cultured carrot cells. Planta 171: 365-376.

Darvill, A.G., P. Albersheim, M. McNeil, J.M. Lau, W.S. York, T.T. Stevenson, J. Thomas, S. Doares, D.J. Gollin, P. Chelf, and K. Davis. 1985. Structure and function of plant cell wall polysaccharides. J. Cell Sci. Suppl. 2: 203-217.

Elbein, A.D. 1987. Inhibitors of the biosynthesis and processing of N-linked oligosaccharide chains. Annu. Rev. Biochem. 56: $497-534$.

Faye, L. and M.J. Chrispeels. 1985. Characterization of N. linked oligosaccharides by affinoblotting with concanavalin A-peroxidase and treatment of the blots with glycosidases. Anal. Biochem. 149: 218-224.

Fry, S.C. 1985. Primary cell wall metabolism. Oxf. Surv. Plant Mol. Cell Biol. 2: 1-42.

- 1986. Cell wall cross-linking. Annu. Rev. Plant Physiol. 37: $165-186$.

Gamborg, O.L., R.A. Miller, and K. Ojima. 1968. Plant cell cultures. Exp. Cell. Res. 50: 151-158.

Giarrocchi, G., R. Cella, and E. Nielsen. 1981. Release of nu- cleotide-cleaving acid phosphatase from carrot cells grown in suspension culture. Physiol. Plant. 53: 375-377.

Giuliano, G., F. LoSchiavo, and M. Terzi. 1984. Isolation and developmental characterization of temperature-sensitive carrot cell variants. Theor. Appl. Genet. 67: 179-183.

Halperin. W. 1966. Alternative morphogenetic events in cell suspensions. Amer. I. Bot. 53: 443-453.

- 1967. Population density effects in embryogenesis in carrot cell cultures. Exp. Cell Res. 48: 170-173.

Hari, V. 1980. Effect of cell density changes and conditioned media on carrot cell embryogenesis. Z. Pflanzenphysiol. 96: $227-231$.

James, R. and A.R. Bradshaw. 1984. Polypeptide growth factors. Annu. Rev. Biochem. 53: 259-292.

Kay, L.E. and D.V. Basile. 1987. Specific peroxidase isozymes are correlated with organogenesis. Plant Physiol. 84:99105.

LoSchiavo, F., G. Giovinazzo, and M. Terzi. 1983. 8-azaguanine resistant carrot cell mutants and their use as universal hybridizers. Mol. Gen. Genet. 192: 326-329.

- 1985. Pattern of polypeptides excreted in the conditioned medium and its alteration in a mutant ts for embryogenesis. In Somatic embryogenesis /ed. M. Terzi, L. Pitto, and Z.R. Sung), pp. 32-34. IPRA, Rome.

LoSchiavo, F., L.A. Quesada-Allue, and Z.R. Sung. 1986. Tunicamycin affects somatic embryogenesis but not cell proliferation in carrot. Plant Sci. 44: 65-71.

McDonagh, J., ed. 1985. Plasma fibronectin: Structure and function. Marcel Dekker, New York.

McNeil, M., A.G. Darvill, S.C. Fry, and P. Albersheim. 1984. Structure and function of the primary cell walls of plants. Annu. Rev. Biochem. 53: 625-663.

Memelink, J., J.H.C. Hoge, and R.A. Schilperoort. 1987. Cytokinin stress changes the developmental regulation of several defense related genes in tobacco. EMBO J. 6: 3579-3584.

Mohnen, D., H. Shinshi, G. Felix, and F. Meins, Jr. 1985. Hormonal regulation of $\beta 1,3$-glucanase messenger RNA levels in cultured tobacco tissues. EMBO /. 4: 1631-1635.

Morrisey, J.H. 1981. Silver stain for proteins in polyacrylamide gels: A modified procedure with enhanced uniform sensitivity. Anal. Biochem. 117: 307-310.

Nomura, K. and A. Komamine. 1986. Molecular mechanisms of somatic embryogenesis. Oxf. Surv. Plant Mol. Cell. Biol. 3: $456-466$.

O'Neill, R.A. and T.K. Scott. 1987. Rapid effects of IAA on cell surface proteins from intact carrot suspension culture cells. Plant. Physiol. 84: 443-446.

Pytela, R., M.D. Perschbacher, and E. Ruoslahti. 1985. Identification and isolation of a $140 \mathrm{kD}$ cell surface glycoprotein with properties expected of a fibronectin receptor. Cell 40: $191-198$.

Roberts, K., C. Grief, G.J. Hills, and P.J. Shaw. 1985. Cell wall glycoproteins: Structure and function. J. Cell Sci. Suppl. 2: $105-127$.

Satoh, S., H. Kamada, H. Harada, and T. Fujii. 1986. Auxin-controlled glycoprotein release into the medium of embryogenic carrot cells. Plant Physiol. 81: 931-933.

Skoog, F. and C.O. Miller. 1957. Chemical regulation of growth and organ formation in plant tissues cultivated in vitro. In Biological action of growth substances. Symp. Soc. Exp. Biol. 11: 118-131.

Smith, J.A. and Z.R. Sung. 1985. Increase in regeneration of plant cells by cross feeding with regenerating Daucus carota cells. In Somatic embryogenesis (ed. M. Terzi, L. Pitto, and Z.R. Sungl, pp. 77-85. IPRA, Rome.

Stafstrom, J.P. and L.A. Staehelin. 1987. A second extensin-like 


\section{de Vries et al.}

hydroxy-proline-rich glycoprotein from carrot cell walls. Plant Physiol. 84: 820-825.

Street, H.E. 1976. Experimental embryogenesis-The totipotency of cultured plant cells. In The developmental biology of plants and animals (ed. C.F. Graham and P.F. Wareing), pp. 73-90. Blackwell, Oxford.

Sung, Z.R. 1976. Turbidimetric determination of plant cell culture growth. Plant Physiol. 57: 460-462.

Sung, Z.R. and R. Okimoto. 1981. Embryonic proteins in somatic embryos of carrot. Proc. Natl. Acad. Sci. 78: 36833687.

1983. Coordinate gene expression during somatic embryogenesis in carrot. Proc. Natl. Acad. Sci. 80: 2661-2665.

Sung, Z.R., A. Feinberg, R. Chorneau, C. Borkird, I. Turner, J. Smith, M. Terzi, F. LoSchiavo, G. Giuliano, L. Pitto, and V. Nuti-Ronchi. 1984. Developmental biology of embryogenesis from carrot cultures. Plant Mol. Biol. Reporter 2: 3-14.

Takeichi, M. 1987. Cadherins: A molecular family essential for selective cell-cell adhesion and animal morphogenesis. Trends Genet. 3: 213-217.

Tamkun, J., D.W. DeSimone, D. Fonda, R.S. Patel, C. Buck, A.F. Horwitz, and R.O. Hynes. 1986. Structure of integrin, a glycoprotein involved in the transmembrane linkage between fibronectin anad actin. Cell 46: 271-282.

Theologis, A. 1986. Rapid gene regulation by auxin. Annu. Rev. Plant Physiol. 37: 407-438.

Thomas, T.L. and D.H. Wilde. 1985. Analysis of gene expression in carrot somatic embryos. In Somatic embryogenesis (ed. M. Terzi, L. Pitto, and Z.R. Sung), pp. 77-85. IPRA, Rome.

- 1987. Analysis of carrot somatic embryo gene expression programs. In Plant biology (ed. C.E. Green, D.A. Folmers, W.T. Hackett, and D.D. Biesboer), vol. 3, pp. 83-93. Alan R. Liss, New York.

Tierney, M.L. and J.E. Varner. 1987. The extensins. Plant Physiol. 84: 1-2.

Tran Thanh Van, K., P. Tonbart, A. Cousson, A.G. Darvill, D.J. Gollin, P. Chelf, and P. Albersheim. 1985. Manipulation of the morphogenetic pathways of tobacco by oligosaccharins. Nature 314: 615-617.

Trewavas, A.J. and R.E. Cleland. 1983. Is plant development regulated by changes in the concentration of growth substances or by changes in the sensitivity to growth substances? TIBS Oct.: 354-357.

Vanderhoef, L.N. and T. Kosuge. 1984. The molecular biology of plant hormone action: Research directions. Workshop summaries. Am. Soc. Plant Physiologists, Rockville MD, USA.

Van Huystee, R.B. 1987. Some molecular aspects of plant peroxidase biosynthetic studies. Annu. Rev. Plant Physiol. 38: $205-219$.

Vergara, M.R., G. Biasini, F. LoSchiavo, and M. Terzi. 1982. Isolation and characterization of carrot cell mutants resistant to $\alpha$-amanatin. Z. Pflanzenphysiologie 107: 313-319.

Wink, M. 1984. Evidence for an extracellular lytic compartment of plant cell suspension cultures: The cell culture medium. Naturwissenschaften 71: 635-638. 


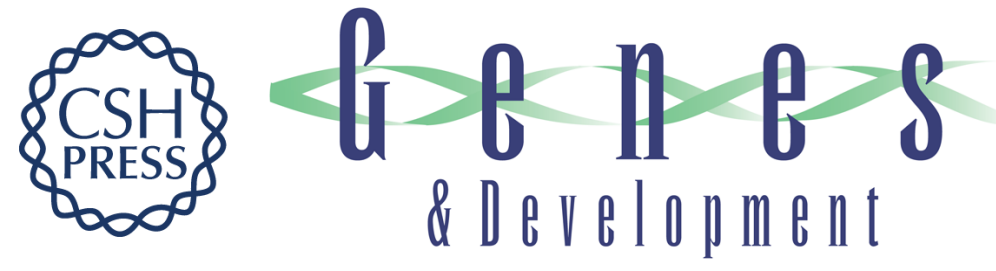

\section{Carrot somatic embryogenesis depends on the phytohormone-controlled presence of correctly glycosylated extracellular proteins}

Genes Dev. 1988, 2:

Access the most recent version at doi:10.1101/gad.2.4.462

References

This article cites 46 articles, 11 of which can be accessed free at: http://genesdev.cshlp.org/content/2/4/462.full.html\#ref-list-1

License

Email Alerting Service
Receive free email alerts when new articles cite this article - sign up in the box at the top right corner of the article or click here.

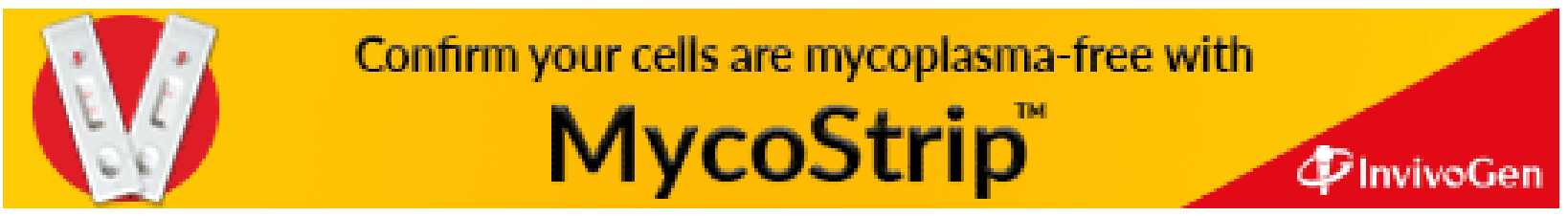

